\title{
DEFINING THE EQUILIBRIUM CONDITION IN A MIXED- SPECIES UNEVEN-AGED FOREST IN SCOTLAND
}

\author{
CAMERON, A. D.* - JANO, G. \\ Institute of Biological and Environmental Sciences, University of Aberdeen, Cruickshank \\ Building, St. Machar Drive, Aberdeen AB22 3UU, Scotland \\ (phone: +44-1224-272-000) \\ *Corresponding author \\ e-mail: a.d.cameron@abdn.ac.uk; phone: +44-1224-272-673 \\ (Received 27 $7^{\text {th }}$ Aug 2018; accepted $15^{\text {th }}$ Oct 2018)
}

\begin{abstract}
Transforming even-aged planted forests into uneven-aged, vertically diverse structures often implies that an equilibrium or sustainable condition will eventually be reached where the stand structure and species composition remains relatively constant over time. However, identifying the equilibrium condition is complicated by the complex dynamics of diverse forest structures. In this study four 'sustainability' indices - stand structure, stocking density, species diversity and increment—were applied over a 20 year period in a long-term permanent sample plot within an uneven-aged forest in Scotland to determine whether the equilibrium condition has been achieved. The Shannon Index of species diversity highlighted a gradual shift towards shade tolerating species. Transition periods (average time for all trees in one diameter class to move into next higher diameter class) of shade tolerating species declined with increasing diameter (trees growing more quickly), whereas the opposite trend was found with light demanding species highlighting competition pressures. However, evaluation of the q value, Lorenz curves, Gini coefficient and Stand Density Index revealed values comparable with those found in longestablished Central European uneven-aged forests and suggests that, while subtle changes in species composition are occurring, the forest is within the range of parameters indicated for the equilibrium condition.
\end{abstract}

Keywords: uneven-aged silviculture, Lorenz curves, Gini coefficient, Stand Density Index, Shannon Index

\section{Introduction}

In many regions of the world, forest cover is dominated by even-aged plantation forests characterised by uniform canopies often of pure coniferous species. There has been increasing pressure in recent years to develop forest ecosystems that are more structurally and species diverse (e.g. Spiecker, 2003), and that are more adaptable to the potential threats of a changing climate (e.g. Millar et al., 2007). The move from predominately clear cutting management (removal of all trees from an area of forest) towards a more ecological or natural approach (i.e. 'uneven-aged', 'irregular', 'selection', 'plenter' or 'close-to-nature' forests) has required a better understanding of the mechanisms of regeneration and seedling/sapling development of species within structurally diverse canopies. Uneven-aged forests are generally described as having vertically varied structures usually comprising a mix of species ranging from new seedlings to mature stems growing within the same space and where a certain level of canopy cover is maintained in perpetuity. The expectation is that these forests will eventually reach a stage of development where, following each harvesting cycle, they revert to the same condition that is often defined as the 'equilibrium' (i.e. 'sustainable', 'stable' or 'balanced') state (e.g. Meyer, 1943; Smith, 1962; Bormann and Likens, 1994; Schütz, 2001). While no forest ecosystem can be regarded as being permanent as 
a result of climatic and human influences that impact over the long lifespans of most forest trees (von Denton, 2011), there remains a desire amongst foresters to achieve some form of equilibrium in uneven-aged forests. This is seen as being important if only to demonstrate that the silvicultural systems used are capable of maintaining a range of economic and environmental services and that these have some degree of permanence.

Determining the equilibrium condition within uneven-aged forests is complicated by the fact that it requires objective, easy-to-use measures that define ways in which management practices influence the relatively complex dynamics of diverse forest structures. O'Hara et al. (2007) pointed out that as forest stands move closer towards a vertically-diverse uneven-aged structure, variations in stand characteristics become more difficult to observe. They suggested four 'sustainability criteria'-stand structure, stand density, species diversity and increment-that they assert are capable of identifying subtle changes in the dynamics of uneven-aged forests. Maintaining the constancy of these measures should ensure that uneven-aged structures achieve a state that could be described as sustainable or in equilibrium, even accepting that some fluctuations are inevitable. Identifying the equilibrium condition would therefore require recurrent assessments of the same area of forest over a period of time to observe whether the equilibrium criteria have been realised.

Distribution of tree size is most commonly used to describe the condition of unevenaged forests although it is not without its critics. The structure of uneven-aged forests was first objectively studied by de Liocourt (1898) through his negative exponential relationship between stem number and diameter (high number of small trees declining exponentially to a few large trees), and continues to be widely seen as a target for uneven-aged stands with the perception that it is both stable and creates 'natural' forest structures (Larsen, 1995). The shape of the negative exponential distribution is expressed by the ratio of decline in number of trees with increasing diameter known as the q value (Meyer, 1952). However, use of the q value and the underlying negative exponential relationship has been challenged by those who believe that it places too great an importance on the stem number-diameter distribution in decisions on unevenaged stand structure and management (e.g. O'Hara, 1998; Schütz and Pommerening, 2013). A study of Central European uneven-aged stands by O'Hara and Gersonde (2004) indicated that there are more trees in the highest and lowest diameter classes than suggested by the q value due to the low growth of the small diameter classes requiring a high number of stems to allow diameter advancement. Once these small stems are released by canopy opening, their increment increases causing a sharp decline in the diameter distribution of the medium size classes. When the trees are larger, mortality declines while diameter class advancement continues to be high resulting in a slower decline in stem number. O'Hara et al. (2007) proposed that Lorenz curves (Lorenz, 1905) and related Gini coefficients (Gini, 1909) are more effective in analysing stand structure since they determine the equality of the population of trees in a stand rather than just the shape of diameter distributions (Weiner and Solbrig, 1984). Lorenz curves were originally developed to analyse economic data, but are widely used in studying forest structure. Lorenz curves define number and size as proportions of the tree population and make the method suitable for comparing stands of different size ranges and those that do not accurately follow the negative exponential distribution or reveal a variable $q$ value; a situation common to most if not all uneven-aged stand structures. The Gini coefficient is a measure of the size of inequality in a stand (Weiner 
and Solbrig, 1984) and is considered to be better than other measures in analysing tree size diversity (Lexerød and Eid, 2006).

Stand density is an important measure of sustainability since successful regeneration and recruitment are dependent on the understorey light environment (Jenkins and Chambers, 1989; Philip, 1994; Mitchell and Popovich, 1997) and is usually represented as the number of trees or basal area per hectare. Foresters commonly adjust stocking density at harvesting interventions by altering basal area (cross-sectional area of all trees per hectare) as a means of effecting changes such as increasing levels of regeneration or to favour certain species in the regeneration mix. Successful regeneration in uneven-aged spruce-fir forests generally requires a basal area of no more than 27-33 $\mathrm{m}^{2} \mathrm{ha}^{-1}$ (Schütz, 2002). A basal area no more than $27 \mathrm{~m}^{2} \mathrm{ha}^{-1}$ has been found to be required for successful regeneration of both intermediate and shade tolerant species (Mailly and Kimmins, 1997; Drever and Lertzmann, 2003; Schütz and Pommerening, 2013), and a lower limit of around $20 \mathrm{~m}^{2} \mathrm{ha}^{-1}$ has been suggested as the point at which competing vegetation inhibits regeneration (Ralston et al., 2004). Species diversity in the understorey, therefore, is strongly influenced by the direction of management in determining an appropriate basal area. An 'equilibrium' basal area and stocking density would have to be set at a level that permits continuous regeneration and recruitment into the canopy, ideally of the preferred species.

While basal area has been widely used to control level of canopy cover, it needs to be considered along with stocking density (number of trees per hectare) to provide a more accurate measure of 'site occupancy' since the maximum basal area that a forest stand can attain increases with tree diameter (Zeide, 2005). Site occupancy is usually expressed as the stand density index (SDI) (Reineke, 1933) and allows objective comparisons to be made between stands at different stages of development. Although SDI was originally developed as a stand density assessment method for single-species, even-aged stands, it has been adapted for use in uneven-aged stands with the aim of controlling stand density through balancing growth among the diameter classes (Sterba and Monserud, 1993; Woodall et al., 2005; Yang et al., 2018).

Many researchers argue that a better determinant of the equilibrium condition is increment, particularly within the saplings and lower diameter classes that will eventually become the future canopy trees (Meyer, 1952; Sterba, 2004; Schütz and Pommerening, 2013). It is suggested that the equilibrium state would require a similar number of trees growing into each diameter class from the next lower class and also trees growing out of the diameter class plus those that are harvested or die (Schütz, 1975). The problem with this approach is that data on tree removals are often unavailable or not recorded using a consistent method to estimate increment across the diameter classes (O'Hara et al., 2007). However, an indicator of the productivity of the standing trees in uneven-aged stands can be derived from increment cores to calculate 'transition periods', defined as the average number of years required for all trees in one diameter class to rise into the next higher diameter class (Čavlović et al., 2006). A feature of long established uneven-aged stands is that transition times decline (i.e. increment increases) with increasing diameter due to young trees in the partially shaded understorey emerging into the canopy where more light is available (Smith et al., 1997).

There have been very few investigations attempting to define the equilibrium condition in spite of the fact that it is a central premise of forest sustainability. The aim of the current study was to determine whether sustainability measures based on stem number and diameter, tree density, species diversity and increment (after O'Hara et al., 
2007) can identify the equilibrium condition. These measures were applied to data collected over a 20 year period from a one hectare permanent sample plot in a rare example of an uneven-aged experimental forest comprising a geographically diverse range of native, Continental European, and North American species, located in Scotland. The stages of this study were analysed as follows: 1) examination of temporal changes in the stem number-diameter distributions, Lorenz curves and Gini coefficients; 2) analysis of increment across diameter classes using transition periods; 3) examination of temporal shifts in canopy and understorey species composition calculated using the Shannon Index of species diversity, and 4) examination of the relationship between stand density and understorey species composition.

\section{Materials and methods}

\section{Study area and permanent sample plot}

The research site is located within Faskally Research Forest, Perthshire, Scotland $\left(56^{\circ} 42^{\prime} 39.4^{\prime \prime} \mathrm{N}, 3^{\circ} 45^{\prime} 45.5^{\prime \prime} \mathrm{W}\right)(\mathrm{Fig} .1)$. The research forest is at $120 \mathrm{~m}$ altitude and has a moist temperate climate with a mean annual precipitation of $900 \mathrm{~mm}$. The geology comprises Dalradian mica schist parent material overlain with brown earth and ironpan soils. The conversion of the forest was started in 1953 in a mature mixed stand of planted Norway spruce (Picea abies (L.) Karst.), Scots pine (Pinus sylvestris L.), European larch (Larix decidua Mill.), Douglas fir (Pseudotsuga menziesii (Mirb.) Franco) and European beech (Fagus sylvatica L.). Gaps were opened in the canopy within a 25 hectare area of the forest and planted with Douglas fir, Norway spruce, western hemlock (Tsuga heterophylla (Raf.) Sarg.), European beech, Scots pine, European larch and silver birch (Betula pendula Roth). Further details on the background of the experimental site are reported in Cameron (2007).

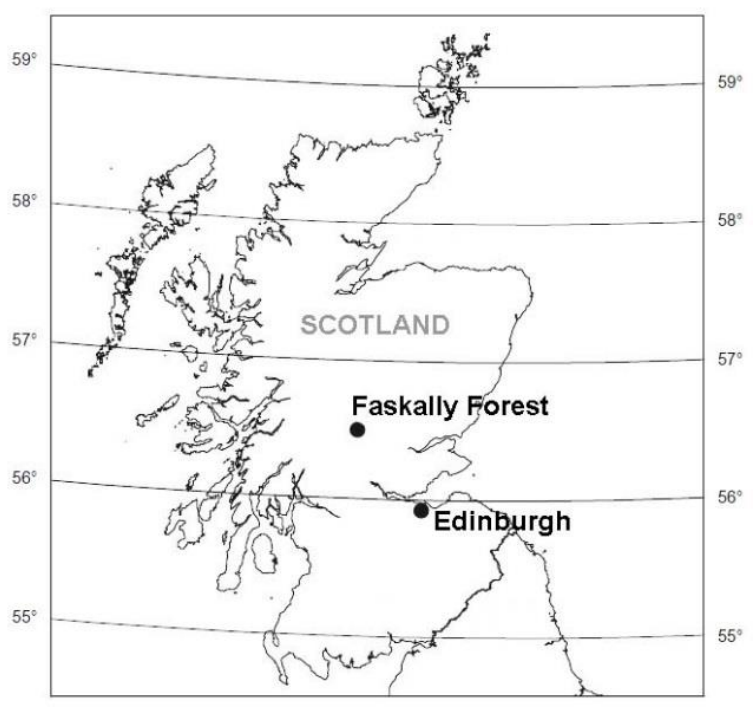

Figure 1. Geographical location of study area

A one hectare permanent sample plot was established in 1997 and complete inventories of the plot (all trees counted and measured) were carried out at this time and 
subsequently in 2003, 2009 and 2015 corresponding with the six-year cutting cycles with the harvesting interventions occurring the year prior to the inventories. Permanent sample plots are favoured as a method of evaluating whether planned management objectives have been applied and whether management interventions have led to the intended structural changes towards a predefined target (Sterba and Ledermann, 2006). It is the principle of re-measuring exactly the same section of forest over time that gives this approach its precision in comparison with random plot surveys. The current study used data from all previous inventories of the one hectare permanent sample plot.

\section{Diameter distributions}

At each inventory, species and stem diameter (DBH - diameter at breast height measured at $1.3 \mathrm{~m}$ from ground level) of all the canopy trees $(\geq 8 \mathrm{~cm} \mathrm{DBH})$ were recorded using diameter tapes based on methods described by Philip (1994). The diameter distributions of the canopy trees were recorded by five centimetre diameter classes based on the mid-point of the class, e.g. $10 \mathrm{~cm}$ class $(8-12 \mathrm{~cm}), 15 \mathrm{~cm}$ class $(13-$ $17 \mathrm{~cm}$ ) and so on (Philip, 1994). The average diminution quotient $\mathrm{q}$ for the canopy trees was calculated by dividing the number of trees in each diameter class by the number of trees in the next higher class.

\section{Regeneration}

A each inventory, a separate survey of seedlings and saplings $(\geq 0.1 \mathrm{~m}$ tall, $<8 \mathrm{~cm}$ DBH) was made using randomly set out $2 \times 2 \mathrm{~m}$ sample grids (Cameron, 2007; Cameron and Hands, 2010; Cameron and Prentice, 2016). In the 2015 inventory, the regeneration was split into seedlings $(\geq 0.1 \mathrm{~m}$ tall, $<3 \mathrm{~cm} \mathrm{DBH})$ and saplings $(3-7 \mathrm{~cm}$ $\mathrm{DBH})$ to provide more detailed information on levels of recruitment into the canopy.

Seedlings and saplings were separated into shade tolerating (shade and intermediate tolerant) and light demanding species. Shade tolerating species have the capacity to germinate, establish, survive and grow in the shade of other plants, whereas light demanding species require full or nearly full light to achieve these attributes. Levels of shade tolerance of species used in this study were based on studies of relative shade tolerance (e.g. Mailly and Kimmins, 1997; Minore, 1979; Schütz, 2002; Drever and Lertzmann, 2003; Hale, 2004; Petritan et al., 2007; Schütz and Pommerening, 2013; Drössler et al., 2017). A summary of the data from the four inventories is shown in Tables 1 and 2.

\section{Lorenz curves, Gini Coefficients and Stand Density Index (SDI)}

Lorenz curves are derived by plotting cumulative relative number of trees against the corresponding cumulative relative diameter or basal area with the upper limit set by the largest tree. Lorenz curves were plotted from data from the full inventories. Curves are generated by ranking the trees by the cumulative proportion of number of trees (y-axis) against the cumulative proportion of both DBH class and basal area (x-axis) (Eq. l).

$$
L(F)=\frac{\int_{0}^{F} x\left(F_{1}\right) d F_{1}}{\int_{0}^{1} x\left(F_{1}\right) d F_{1}}
$$

where $L(F)=$ Lorenz curve, $F=$ cumulative proportion of trees, $F(x)=$ cumulative distribution function and $x(F)=$ inverse cumulative distribution function. 
Table 1. Number of canopy trees $(\geq 8 \mathrm{~cm} D B H)$ by species, basal area and $q$ value within the one hectare permanent sample plot measured in 1997, 2003, 2009 and 2015. (Source: Cameron and Prentice, 2016)

\begin{tabular}{|c|c|c|c|c|}
\hline \multirow{2}{*}{ Species } & \multicolumn{4}{|c|}{ Number of trees ha ${ }^{-1}$} \\
\hline & 1997 & 2003 & 2009 & 2015 \\
\hline Pseudotsuga menziesii & 222 & 174 & 119 & 112 \\
\hline Picea abies & 116 & 130 & 71 & 55 \\
\hline Larix decidua & 86 & 39 & 58 & 43 \\
\hline Pinus sylvestris & 83 & 46 & 52 & 36 \\
\hline Tsuga heterophylla & 32 & 15 & 6 & 6 \\
\hline Abies procera & 0 & 0 & 2 & 2 \\
\hline Betula pendula & 97 & 71 & 59 & 56 \\
\hline Fagus sylvatica & 30 & 29 & 15 & 19 \\
\hline Acer pseudoplatanus & 0 & 0 & 2 & 4 \\
\hline Sorbus aисuparia & 0 & 0 & 0 & 3 \\
\hline Ilex aquifolium & 0 & 0 & 0 & 1 \\
\hline Total number of trees ha- ${ }^{-1}$ & 666 & 504 & 384 & 337 \\
\hline Basal area $\left(\mathrm{m}^{2} \mathrm{ha}^{-1}\right)$ & 32 & 27 & 28 & 26 \\
\hline q value & 1.6 & 1.5 & 1.4 & 1.4 \\
\hline
\end{tabular}

Table 2. Number of seedlings $(\geq 0.1 \mathrm{~m}$ tall, $<3 \mathrm{~cm} \mathrm{DBH})$ and saplings $(3-7 \mathrm{~cm} \mathrm{DBH})$ within the one hectare permanent sample plot measured in 1997, 2003, 2009 and 2015. Seedlings and saplings are split in the 2015 inventory. $S=$ shade tolerant, $I=$ intermediate tolerance, $L=$ light demanding. (Source: Cameron and Prentice, 2016)

\begin{tabular}{c|c|c|c|c|c|c}
\hline \multirow{2}{*}{ Species } & \multirow{2}{*}{$\begin{array}{c}\text { Shade } \\
\text { tolerance }\end{array}$} & $\mathbf{1 9 9 7}$ & $\mathbf{2 0 0 3}$ & $\mathbf{2 0 0 9}$ & \multicolumn{2}{|c}{$\mathbf{2 0 1 5}$} \\
\cline { 4 - 7 } & & & & & Seedlings & Saplings \\
\hline Pseudotsuga menziesii & I & 197 & 401 & 542 & 958 & 27 \\
Picea abies & I & 158 & 339 & 500 & 1042 & 69 \\
Larix decidua & L & 53 & 92 & 83 & 83 & 13 \\
Pinus sylvestris & L & 0 & 0 & 42 & 167 & 0 \\
Tsuga heterophylla & S & 3 & 278 & 1417 & 1833 & 41 \\
Picea sitchensis & I & 0 & 31 & 0 & 0 & 1 \\
Abies grandis & S & 0 & 0 & 126 & 250 & 0 \\
Abies procera & S & 0 & 0 & 42 & 42 & 0 \\
Fagus sylvatica & S & 244 & 247 & 1208 & 1417 & 52 \\
Betula pendula & L & 33 & 0 & 208 & 125 & 2 \\
Sorbus aucuparia & I & 0 & 0 & 167 & 1083 & 3 \\
Acer pseudoplatanus & I & 0 & 0 & 125 & 0 & 0 \\
Ilex aquifolium & S & 0 & 0 & 0 & 42 & 1 \\
\hline Total & & 688 & 1388 & 4460 & 7042 & 209 \\
\hline
\end{tabular}

The Gini coefficient measures the 'bow' of the Lorenz curve, and equals the area between the curve and the line of equality $\left(45^{\circ}\right)$ divided by the total area of the triangle 
below the $45^{\circ}$ line. The Gini coefficient ranges from a minimum value of 0 , where all values are equal, to a theoretical maximum of 1 representing total inequality (an infinite population where all individuals except one have a value of 0) (Weiner and Solbrig, 1984; Eq. 2).

$$
G=1-\sum_{k=1}^{n}\left(X_{k}-X_{k-1}\right)\left(Y_{k}+Y_{k-1}\right)
$$

where $G=$ Gini coefficient, $\mathrm{X}_{\mathrm{k}}=$ cumulated proportion of diameter class variable for $\mathrm{k}=0, \ldots, \mathrm{n}$, with $\mathrm{X}_{0}=0, \mathrm{X}_{\mathrm{n}}=1 ., \mathrm{Y}_{\mathrm{k}}=$ cumulated proportion of stem number, for $\mathrm{k}=0, \ldots, \mathrm{n}$, with $\mathrm{Y}_{0}=0, \mathrm{Y}_{\mathrm{n}}=1$.

A high Gini coefficient indicates that the distribution of diameters or basal areas is very heterogeneous whereas a low Gini coefficient indicates more homogenous stands with a limited spread of tree sizes. Uneven-aged forest stands would expected to have higher and more stable values of Gini coefficient than even-aged stands (O'Hara et al., 2007).

Stand density index (SDI) is defined as the number of trees per hectare when the quadratic mean diameter of the stand is established at the index value of $25 \mathrm{~cm}$ (Reineke, 1933). SDI was determined for each inventory by calculating the index for each individual diameter class then summing for the whole stand (Woodall et al., 2005; Eq. 3):

$$
S D I=\sum T P H i\left(\frac{D B H i}{25}\right)^{1.6}
$$

where SDI $=$ Stand Density Index, $\mathrm{DBH}_{\mathrm{i}}=$ midpoint of the ith diameter class $(\mathrm{cm})$ and $\mathrm{TPH}_{\mathrm{i}}=$ number of trees per hectare in the ith diameter class.

\section{Shannon Indices of species diversity}

Shannon Indices (Spellerberg and Fedor, 2003) were calculated for the canopy trees and understorey regeneration using data of the broadleafs and conifers, and shade tolerating and light demanding species (from Table 2) using the formula (Eq. 4):

$$
S I=-\sum_{i=1}^{n} p_{i} * \ln p_{i}
$$

where SI $=$ Shannon Index and $p_{i}=$ proportion of the total number of trees. SI increases with increasing number of trees and increasing number of species. It is therefore sensitive to both species richness and species evenness.

\section{Transition periods and annual recruitment}

Transition periods (after Čavlović et al., 2006) were calculated from a sample of 90 trees randomly selected within the one hectare permanent sample plot in the spring of 2017. To ensure a representative sample of stem sizes, stratified random sampling was carried out across three size classes (small trees $8-25 \mathrm{~cm}$ DBH, medium trees $25-40 \mathrm{~cm}$ $\mathrm{DBH}$, large trees $>40 \mathrm{~cm} \mathrm{DBH})$. The species and $\mathrm{DBH}$ were recorded and increment cores removed from the outer $30 \mathrm{~mm}$ of each sample tree. Cores were taken at $1.3 \mathrm{~m}$ height on the north side of each tree and the number of annual rings in the first $25 \mathrm{~mm}$ from the bark were counted. Transition periods (years for all trees in a diameter class to move into the next diameter class) were calculated for each diameter class from the 
increment cores. Transition period for the $10 \mathrm{~cm}$ class was calculated using the formula (Eq. 5):

$$
T_{10}=\frac{10\left(D B H_{u I}-D B H\right)}{2\left(\frac{25}{N_{\text {rings }}}\right)}
$$

where $\mathrm{T}_{10}=$ transition period for the $10 \mathrm{~cm} \mathrm{DBH}$ class, $\mathrm{DBH}_{\mathrm{ul}}=$ upper limit of the DBH class and $\mathrm{N}_{\text {rings }}=$ number of rings in the outer $25 \mathrm{~mm}$ of each core. Pearson's correlations ( $\mathrm{r}$ ) were determined between transition period and DBH class. Annual recruitment into the $10 \mathrm{~cm} \mathrm{DBH}$ class was calculated using the formula (Eq. 6):

$$
R_{10}=\frac{\left(N_{5}+N_{10}\right)}{2 T_{10}}
$$

where $\mathrm{R}_{10}=$ annual recruitment into the $10 \mathrm{~cm}$ DBH class (trees per hectare), $\mathrm{N}_{5}=$ number of trees in the $5 \mathrm{~cm} \mathrm{DBH}$ class $(3-7 \mathrm{~cm}), \mathrm{N}_{10}=$ number of trees in the $10 \mathrm{~cm}$ DBH class $(8-12 \mathrm{~cm})$ and $\mathrm{T}_{10}=$ transition period for the $10 \mathrm{~cm} \mathrm{DBH}$ class (years).

\section{Results}

\section{Analysis of stand structure}

The shape of the stem number-diameter distribution has changed over the four inventories of the permanent sample plot with a 'flattening' of the curve (Fig. 2) as a result of a reduction in tree density (Table 1) mainly in the smaller size categories.

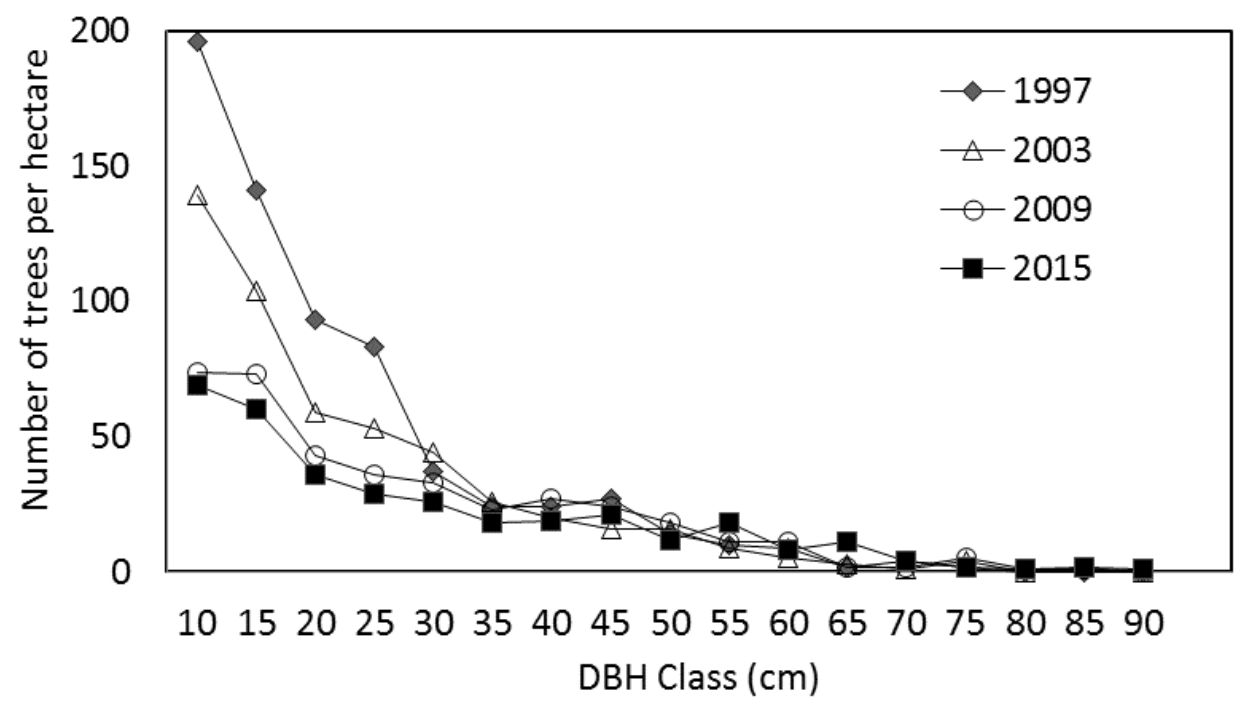

Figure 2. Diameter distribution of canopy trees $(\geq 8 \mathrm{~cm} D B H)$ recorded in the one hectare permanent sample plot in 1997, 2003, 2009 and 2015

The current stem number-diameter distribution (2015 inventory) shows an approximate exponential relationship when compared with an 'idealised' negative exponential curve fitted to the data (Fig. 3). 


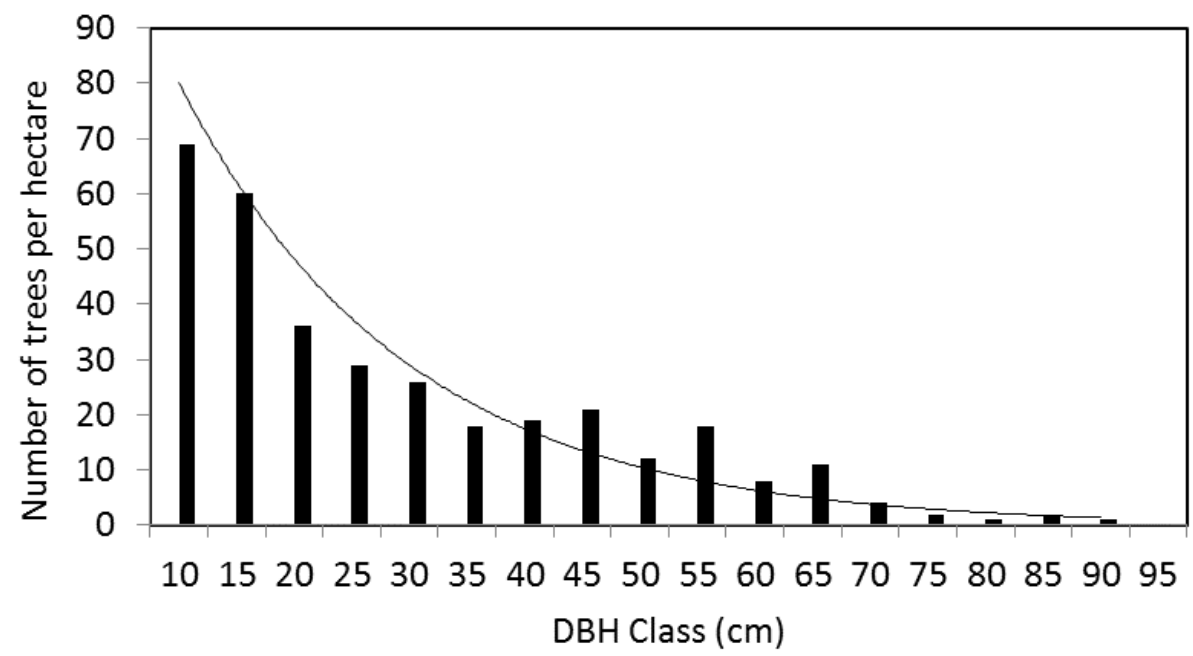

Figure 3. Diameter distribution of canopy trees $(\geq 8 \mathrm{~cm}$ DBH) measured in 2015 (fitted 'ideal' negative exponential curve $y=103.16 e^{-0.253 x}$ )

The Lorenz curves indicate that a change in shape of the cumulative distribution of DBH and number of trees has occurred between 1997 and 2015 inventories (Fig. 4) with the curves becoming flatter particularly in the last two inventories of 2009 and 2015. The declining Gini coefficients (calculated from DBH) indicate that the heterogeneity of the stand has increased between 1997 and 2015 (Table 3). Lorenz curves derived from basal area and cumulative proportion of number of trees in the 2009 and 2015 inventories show a clear shift from one of side of the equality line $\left(45^{\circ}\right)$ to the other (Fig. 4) reflecting a shift in the impact of the smaller trees towards the larger trees in the basal area distribution. The movement of the Gini coefficients (calculated from basal area) towards zero highlights the greater balance between smaller and larger trees by the 2015 inventory (Table 3). SDI, a measure of the occupancy of the stand, shows a decline from 629 to 485 between the 1997 and 2015 inventories (Table 3), and reflects the overall reduction in 'site occupancy' by the canopy trees over this period.

Table 3. Gini coefficients and Stand Density Indices (SDI) calculated from inventories of 1997, 2003, 2009 and 2015

\begin{tabular}{c|c|c|c|c}
\hline & \multicolumn{4}{|c}{ Year of inventory } \\
\cline { 2 - 5 } & $\mathbf{1 9 9 7}$ & $\mathbf{2 0 0 3}$ & $\mathbf{2 0 0 9}$ & $\mathbf{2 0 1 5}$ \\
\hline $\begin{array}{c}\text { Gini coefficient } \\
\text { (DBH) }\end{array}$ & 0.66 & 0.64 & 0.53 & 0.50 \\
$\begin{array}{c}\text { Gini coefficient } \\
\text { (basal area) }\end{array}$ & 0.25 & 0.15 & 0.10 & 0.01 \\
$\begin{array}{c}\text { SDI (uneven-aged } \\
\text { formula) }\end{array}$ & 629 & 516 & 508 & 485 \\
\hline
\end{tabular}

\section{Proportion of shade tolerating and light demanding species in the canopy}

An examination of the proportions of shade tolerating and light demanding coniferous and broadleaved species by diameter class from the 2015 inventory of the 
permanent sample plot indicates that nearly $80 \%$ of species in the $10 \mathrm{~cm}$ diameter class are shade tolerating and dominated by conifers (Fig. 5).

\section{Species diversity}

The Shannon Index (SI) for the understorey species diversity was at its lowest at the start of the study in 1997 (SI = 1.43), and has steadily increased by 2015 (SI = 1.91) (Fig. 6). The SI of canopy tree diversity has not varied greatly over the four inventories and this is evident when split by shade tolerance and by conifers and broadleafs. The SI of the understorey species (Fig. $7 \mathrm{~b}$ ) indicates that the diversity of shade tolerating species has increased in the understorey while the Index for light demanding species has remained relatively stable. Diversity of coniferous species in the understorey has gradually increased since 1997, whereas diversity of broadleaved species has fluctuated slightly although remaining relatively stable in 2009 and 2015.
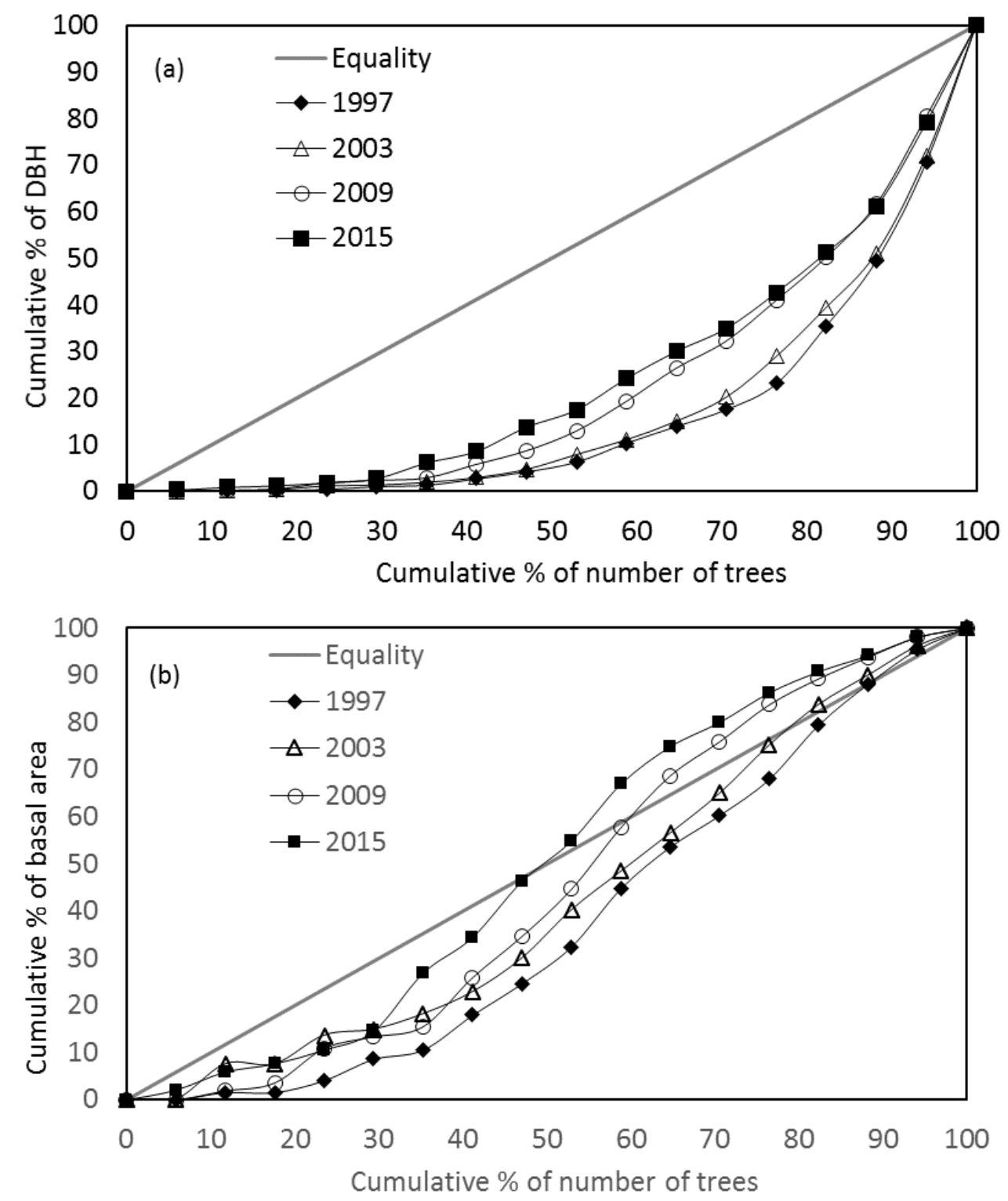

Figure 4. Lorenz curves for cumulative \% of DBH (diameter at $1.3 \mathrm{~m})(\mathrm{a})$ and basal area $(\mathrm{b})$ against number of trees measured in1997, 2003, 2009 and 2015 


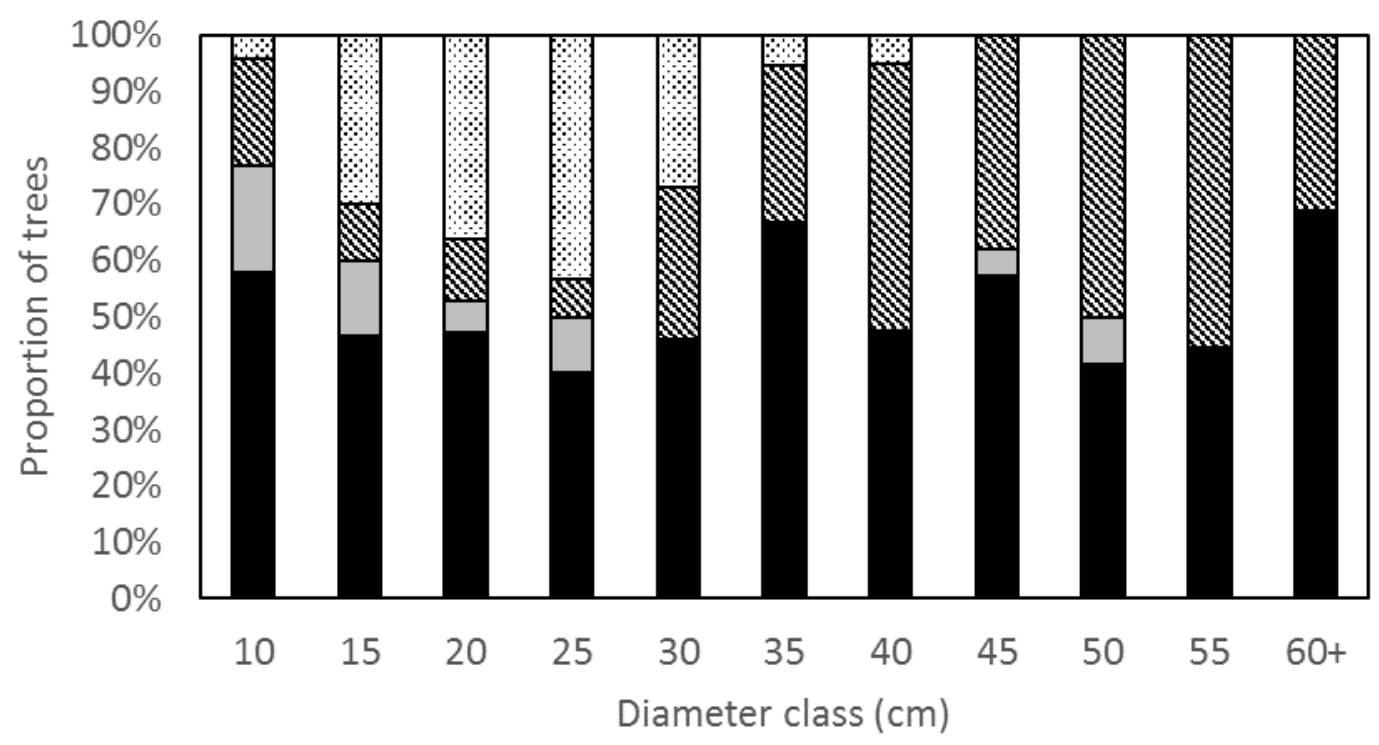

- Shade tolerating conifers

$\square$ Shade tolerating broadleafs

Light demanding conifers

ㄴ. Light demanding broadleafs

Figure 5. Proportional distributions of coniferous and broadleaved canopy trees (DBH $\geq 8 \mathrm{~cm})$ relative to their shade tolerance measured in 2015

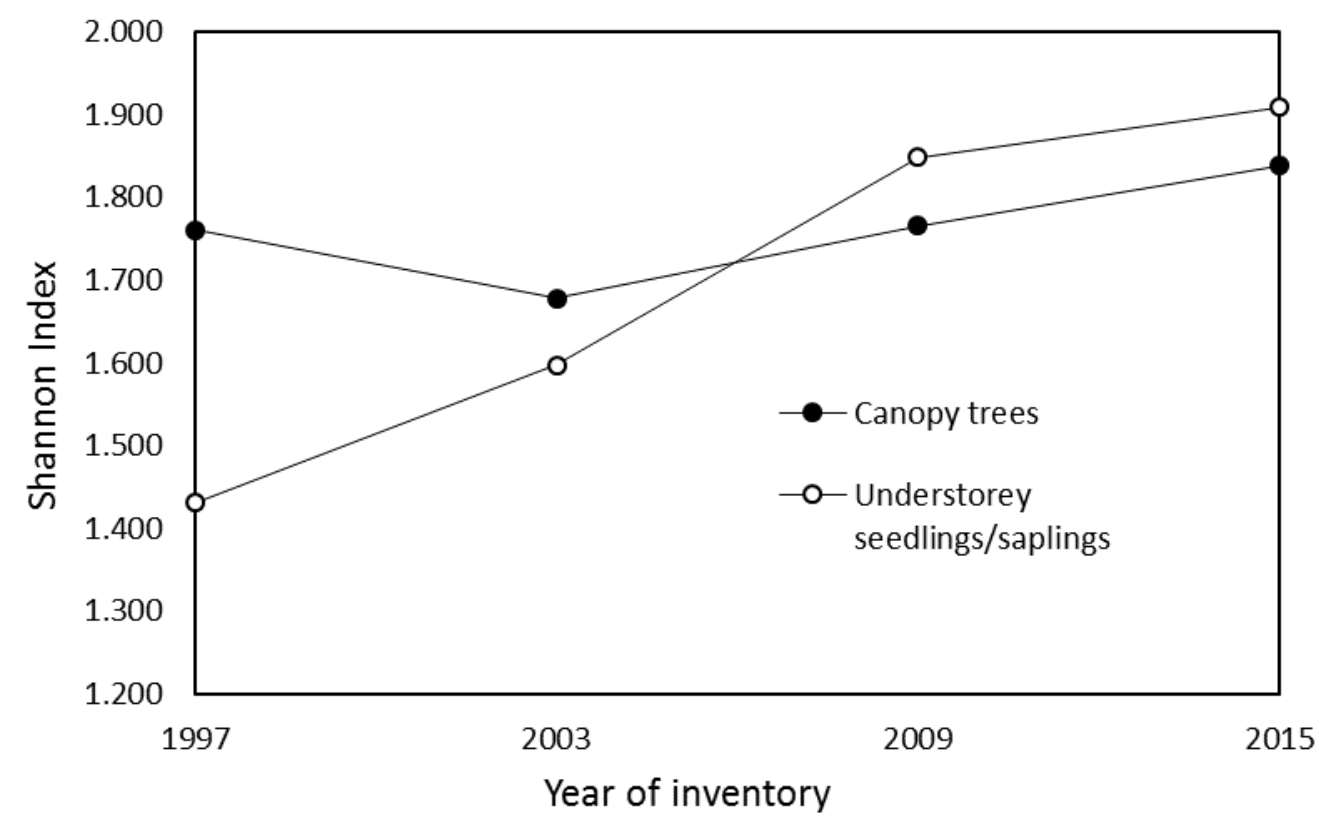

Figure 6. Shannon Index for diversity of canopy trees and understorey seedlings and saplings measured in 1997, 2003, 2009 and 2015 (y axis truncated)

\section{Recruitment of shade tolerating and light demanding species}

Transition periods for the shade tolerating species declined with tree size indicating faster growth as the trees become larger (Fig. 8). The opposite trend was observed for light demanding species with the tendency for growth of these trees to decline with 
increasing diameter. The average levels of annual recruitment were considerably higher for shade tolerating species in comparison with light demanding species indicating that more trees were being recruited into each diameter class (Table 4).
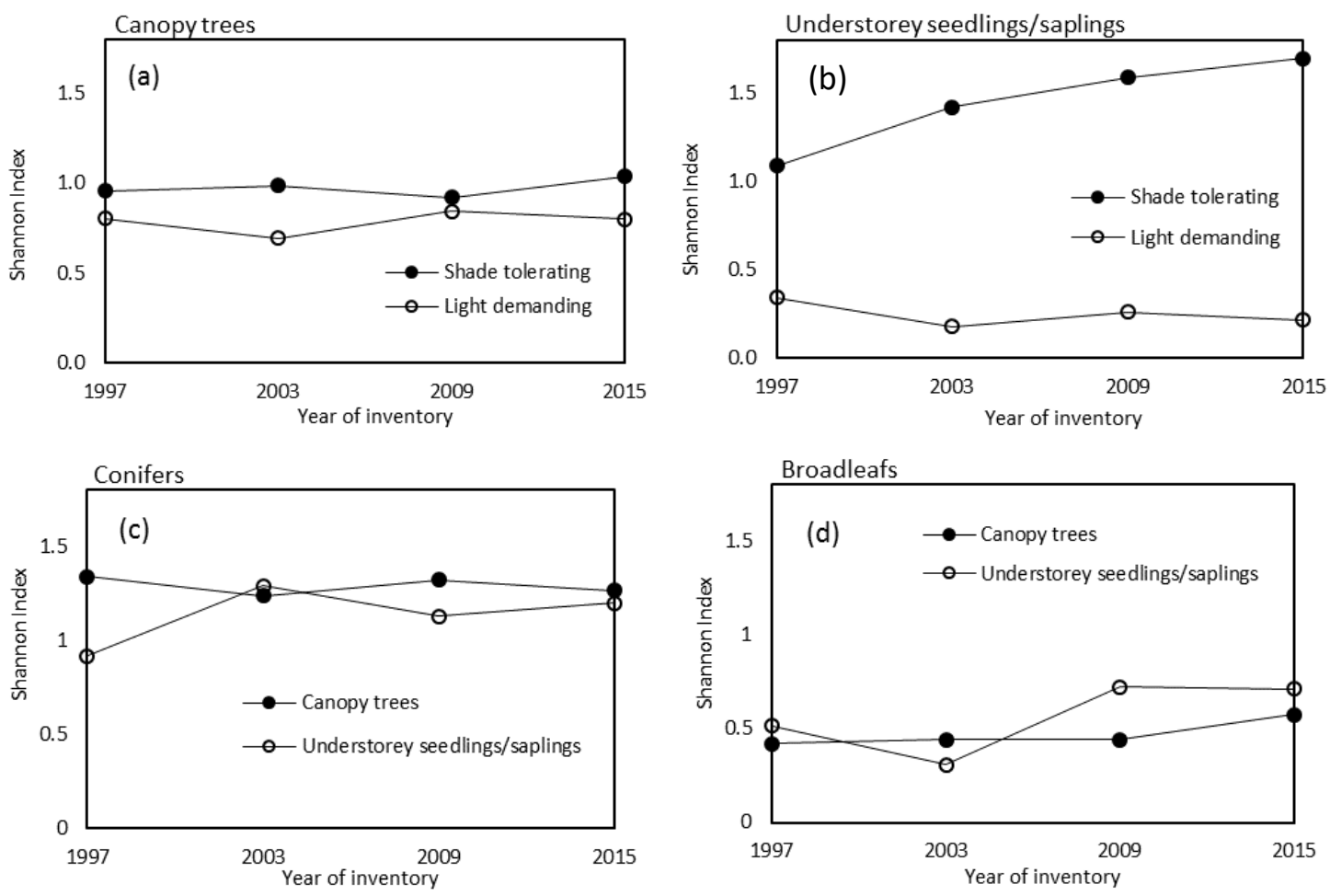

Figure 7. Shannon Index of diversity of species by shade tolerance in the canopy $(a)$ and understorey (b), and separated by conifers (c) and broadleafs (d) measured in 1997, 2003, 2009 and 2015

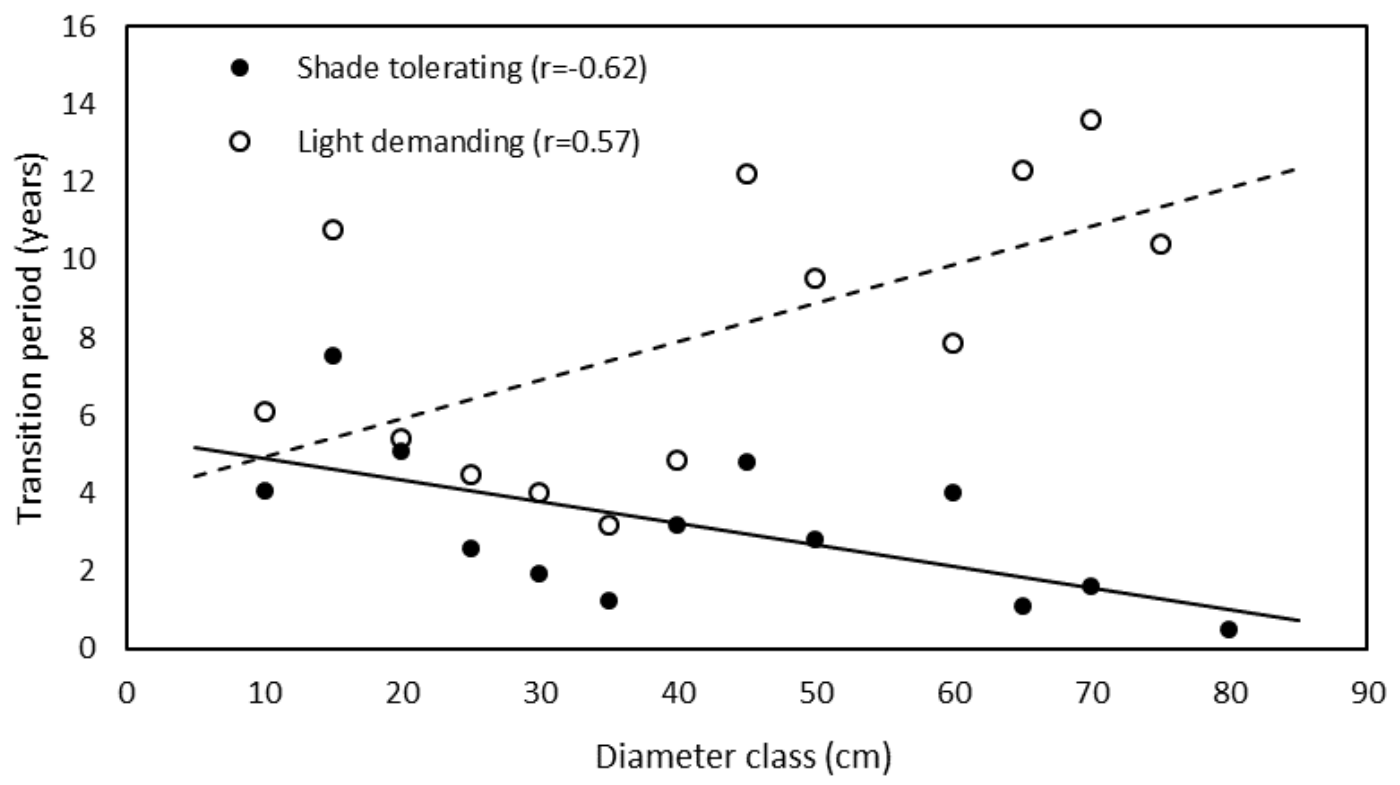

Figure 8. Transition periods by diameter class and trend lines for shade tolerating (solid line) and light demanding (dashed line) species 
Table 4. Annual recruitment by diameter class for light demanding and shade tolerating species in 2015

\begin{tabular}{c|c|c}
\hline \multirow{2}{*}{ Diameter class (cm) } & \multicolumn{2}{|c}{ Annual recruitment (trees ha $\left.\mathbf{~ y e a r}^{-1}\right)$} \\
\cline { 2 - 3 } & Light demanding & Shade tolerating \\
\hline 10 & 3.770 & 28.448 \\
15 & 2.269 & 5.159 \\
20 & 2.037 & 6.809 \\
25 & 0.556 & 10.742 \\
30 & 0.875 & 11.897 \\
35 & 1.406 & 12.800 \\
40 & 1.546 & 3.125 \\
45 & 0.984 & 1.771 \\
50 & 0.944 & 2.857 \\
55 & 0.953 & - \\
60 & 0.527 & 1.500 \\
65 & 0.221 & 5.909 \\
70 & 0.096 & 3.750 \\
75 & - & - \\
80 & - & - \\
85 & - & 0.139 \\
\hline Mean & 1.24 & 7.30 \\
\hline
\end{tabular}

\section{Discussion and conclusion}

While results indicate that the negative exponential relationship of the stem numberdiameter distribution represents the all-aged, all-sized structure widely recognised in uneven-aged 'plenter' forests, Schütz (2002) pointed out that due to natural stand differentiation as a result of competition between species and individual trees, evidence of diameter variation is not on its own a valid indicator of age range or vertical structure. Using Lorenz curves based on stem diameter has highlighted a flattening of the stem number-diameter distribution with each inventory underlining the decline in the number of trees in the smaller diameter classes relative to the larger tree sizes. The associated decline in the Gini coefficients has shown that the diameter distribution has become less heterogeneous since the start of the study indicating a slight decline in the number of smaller trees. Nevertheless, the value of the Gini coefficient at the last inventory in $2015(0.50)$ is in the middle of the range reported for uneven-aged boreal forests (0.44-0.57) (Lexerød and Eid, 2006) and within the range for plenter stands in Central Europe (O'Hara et al., 2007) ( 0.4-0.7). These observations suggest that a Gini coefficient of around 0.50 is probably representative of a relatively stable uneven-aged stand structure. Significantly higher values would indicate greater inequality suggesting too many small or large trees or a diameter distribution deviating substantially from the negative exponential curve. Too small a Gini coefficient would indicate a substantial flattening of the negative exponential distribution that would result in too few trees in the smaller size classes for adequate recruitment into the higher classes and the stand may become unsustainable. When the Lorenz curves and Gini coefficients are calculated using cumulative basal area, the Lorenz curves representing the last two inventories have moved across the 'equality line' due to the greater effect of the bigger 
trees within the population as a direct result of the reduction of trees in the smaller size categories following the 1997 inventory. The associated Gini coefficient has been reduced to close to zero or equality indicating a relative balance in basal areas across the size classes, a distribution that has been suggested as potentially demonstrating a sustainable or equilibrium state (Cameron, 2007).

Since SDI (stand density index) has not been used widely in uneven-aged, mixed species forests (Woodall et al., 2005), comparable data are limited. Although there has been a decline in SDI, stocking density and basal area (representing a reduction in site occupancy) over the four inventories of this study, values from the 2015 inventory are surprisingly similar to those reported by Adamic et al. (2017) for managed, unevenaged forests in Slovenia (values for current study in parentheses): SDI = 504 (485), stocking density (trees ha $\left.{ }^{-1}\right)=345$ (337) and basal area $\left(\mathrm{m}^{2} \mathrm{ha}^{-1}\right)=29$ (26), indicating that site occupancy is probably within an acceptable range to maintain a steady stream of regeneration and recruitment into the canopy.

While species diversity of the canopy trees over the study period has not changed greatly, mainly due to the relatively small proportion of the canopy removed at each harvesting intervention, species diversity in the understorey has increased and this is entirely formed of shade tolerating species. This is a widely recognised feature of uneven-aged forests where the partially shaded conditions favour shade tolerance in the understorey species. These species are also growing faster than light demanding species with higher annual recruitment in all diameter classes, and further emphasises the favourable environment for shade tolerating species. The few light demanding species that do move into the canopy are subject to competition for crown development limiting their growth potential as observed through the increasing transition periods (trees growing more slowly with increasing size) whereas transition periods are declining (trees growing faster with increasing size) with shade tolerating species. This trend in the transition periods of shade tolerating species is consistent with the development of trees in uneven-aged stands where young trees emerge from the shaded understorey environment moving up into the canopy where higher light levels and more space permit canopy expansion and greater growth (Knuchel, 1953; Assmann, 1970; Smith et al., 1997).

The gradual shift towards shade tolerating species observed at the study site is unlikely to influence current stand structure if continuous regeneration and recruitment into the lower classes balance losses through competition and harvesting. It has been suggested that the dominance of shade tolerating species in uneven-aged forests is due to their greater resilience to changing environmental conditions within the understorey, with some species of Abies and Picea capable of surviving in a quasi-stationary state for a long time until they are released by the presence of small canopy gaps (Whitmore, 1989, Schütz, 2002). This allows the density of trees in uneven-aged stands to be relatively high (Schütz and Pommerening, 2013), which further increases the competitive pressure on light demanding species. In the longer term, what is lost from the population of light demanding species is likely to be balanced by an increase in shade tolerating species leaving overall species diversity largely unchanged.

Claiming that an uneven-aged forest has reached an equilibrium condition often implies that some optimum or target structure has to be first determined and that this structure remains in a relatively stable condition over some accepted period of time. However, deciding on a timescale over which a level of constancy in structure and function of uneven-aged stands indicating a sustainable state has never been 
satisfactorily resolved. It could be argued that the timescale over which the current study was carried out is too short to indicate an equilibrium condition; yet the longer the observation period becomes, the more likely that influences of climate and management direction will force change anyway (e.g. von Detten, 2011), and this raises the issue of whether it is realistic to set target equilibrium structures in the first place. O'Hara et al. (2007) found that long-term uneven-aged forests in Central Europe showed significant variation in stand structure, stocking density, species diversity and increment over periods of decades, and suggested that these forests are still evolving and that there is no single ideal structure. They stated that the resilience of uneven-aged forests may be due more to the flexibility of predominantly shade tolerant species in vertically diverse stands (Ibid.) than a rigorous approach to management with the aim of maintaining stable stand structures over time. Sterba (2004) suggested several equilibrium conditions are possible for uneven-aged stands and that there is no one ideal stand structure. Criticism of rigid definitions of optimal stand structures is not new and Henri Biolley, who was instrumental in the early development of selection systems, emphasised that uneven-aged stands should not be developed by reference to theoretical size-class distributions and instead should be managed on purely silvicultural grounds (Biolley, 1934). A flexible interpretation of the equilibrium condition would suggest that the current structure of the uneven-aged stand in this study is close to an equilibrium state even if it is accepted that a very gradual shift in species composition will inevitably take place; a view supported by Sterba (2004) who pointed out that stable diameter distributions do not necessarily show stable species distributions.

Unless there is a dramatic change in canopy cover that would influence the future passage of regeneration and recruitment into the canopy, there is no reason why the uneven-aged forest in this study under the current management regime will not continue long into the future as a relatively stable, vertically-structured, species-diverse stand. This study has also demonstrated that species from diverse geographic origins appear to be capable of forming relatively stable vertically-structured stands. This is important where foresters feel the need to diversify the species composition within their forests using a wide range of alternative species as a means of building resilience to a changing climate (Linder and Cramer, 2002; Woods, 2003; Pretzsch, 2003; Cameron, 2015). Future research will continue to focus on the gradual evolution of this forest in terms of structural diversity and tree species composition with the aim of determining whether a final stable forest structure can be achieved. The experimental site will also be used in future studies to estimate the net primary production of structurally diverse forests in terms of their potential to sequester atmospheric carbon, and how this compares with even-aged forest structures.

Acknowledgements. The authors wish to thank the staff of Tay Forest District, Forestry Commission Scotland for their support in carrying out this study.

\section{REFERENCES}

[1] Adamic, M., Diaci, J., Rozman, A., Hladnik, D. (2017): Long-term use of uneven-aged silviculture in mixed mountain Dinaric forest: a comparison of old-growth and managed stands. - Forestry 90: 279-291.

[2] Assmann, E. (1970): Principles of Forest Yield Study. - Pergamon Press, Oxford. 
[3] Biolley, H. (1934): Nombres d'arbres et régimes de futaies. - Journal Forestier Suisse 48: 27-33.

[4] Bormann, F. H., Likens, G. E. (1994): Pattern and Process in a Forested Ecosystem: Disturbance, Development and the Steady State Based on the Hubbard Brook Ecosystem Study. - Springer-Verlag, Berlin.

[5] Cameron, A. (2007): Determining the sustainable normal irregular condition: A provisional study on a transformed, irregular mixed species stand in Scotland. Scandinavian Journal of Forest Research 22: 13-21.

[6] Cameron, A. D. (2015): Building resilience into Sitka spruce (Picea sitchensis [Bong.] Carr.) forests in Scotland in response to the threat of climate change. - Forests 6: 398415.

[7] Cameron, A. D., Hands, M. O. R. (2010): Developing a sustainable irregular structure: an evaluation of three inventories at 6-year intervals in an irregular mixed-species stand in Scotland. - Forestry 83: 469-475.

[8] Cameron, A. D., Prentice, L. (2016): Determining the sustainable irregular condition: an analysis of an irregular mixed-species selection stand in Scotland based on recurrent inventories at 6-year intervals over 24 years. - Forestry 89: 208-214.

[9] Čavlović, J., Božić, M., Boncina, A. (2006): Stand structure of an uneven-aged fir-beech forest with an irregular diameter structure: modelling the development of the Belevine forest, Croatia. - European Journal of Forest Research 125: 325-333.

[10] De Liocourt, F. (1898): De L'aménagement des sapinieres. - Bulletin de la Société forestière de Franche-Compté et des Provinces de l'Est: 396-409.

[11] Drever, C. R., Lertzman, K. P. (2003): Effects of a wide gradient of retained tree structures on understorey light in coastal Douglas fir forests. - Canadian Journal of Forest Research 33: 137-146.

[12] Drössler, L., Fahlvik, N., Wysocka, N., Hjelm, K., Kuehne, C. (2017): Natural regeneration in a multi-layered Pinus sylvestris-Picea abies forest after target diameter harvest and soil scarification. - Forests 8: 35-49.

[13] Gini, C. (1909): Concentration and dependency ratios (in Italian). - English translation in Rivista di Politica Economica 87 (1997): 769-789.

[14] Hale, S. E. (2004): Managing light to encourage natural regeneration in British conifer forests. - Forestry Commission Information Note 63. Forestry Commission, Edinburgh.

[15] Jenkins, M. W., Chambers, J. L. (1989): Understorey light levels in mature hardwood stands after partial overstorey removal. - Forest Ecology and Management 26: 247-256.

[16] Knuchel, H. (1953): Planning and Control in the Managed Forest (English translation by M. L. Anderson). - Oliver \& Boyd, Edinburgh and London.

[17] Larsen, J. B. (1995): Ecological stability for forests and sustainable silviculture. - Forest Ecology and Management 73: 85-96.

[18] Lexerød, N. L., Eid, T. (2006): An evaluation of different diameter diversity indices based on criteria related to forest management planning. - Forest Ecology and Management 222: 17-28.

[19] Lindner, M., Cramer, W. (2002): Wälder und Forstwirtschaft Deutschlands im globalen Wandel: Eine interdisziplinäre Wirkungsanalyse (German forest sector under global change: An interdisciplinary impact assessment). - Forstwissenschaftliches Zentralblatt 121: 3-17.

[20] Lorenz, M. O. (1905): Methods of measuring the concentration of wealth. - American Statistical Association 9: 209-219.

[21] Mailly, D., Kimmins, J. P. (1997): Growth of Pseudotsuga menziesii and Tsuga heterophylla seedlings along a light gradient: resource allocation and morphological acclimation. - Canadian Journal of Botany 75: 1424-1435.

[22] Meyer, H. A. (1943): Management without rotation. - Journal of Forestry 41: 126-132.

[23] Meyer, H. A. (1952): Structure, growth and drain in balanced uneven-aged forests. Journal of Forestry 50: 85-92. 
[24] Millar, C. I., Stephenson, N. L., Stephens, S. L. (2007): Climate change and forest of the future: managing in the face of uncertainty. - Ecological Applications 17: 2145-2151.

[25] Minore, D. (1979): Comparative Autecological Characteristics of Northwestern Tree Species: A Literature Review (Gen. Tech. Rep. PNW-87). - US Department of Agriculture Forest Service, Washington, DC.

[26] Mitchell, J. E., Popovich, S. J. (1997): Effectiveness of basal area for estimating canopy cover of ponderosa pine. - Forest Ecology and Management 95: 45-51.

[27] O'Hara, K. L. (1998): Silviculture for structural diversity: a new look at multi-aged systems. - Journal of Forestry 96: 4-10.

[28] O’Hara, K. L., Gersonde, R. F. (2004): Stocking control concepts in uneven-aged silviculture. - Forestry 77: 131-143.

[29] O'Hara, K. L., Hasenauer, H., Kindermann, G. (2007): Sustainability in multi-aged stands: an analysis of long-term plenter systems. - Forestry 80: 163-181.

[30] Petritan, A. M., von Lupke, B., Petritan, I. C. (2007): Effects of shade on growth and mortality on maple (Acer pseudoplatanus), ask (Fraxinus excelsior) and beech (Fagus sylvatica) seedlings. - Forestry 80: 397-412.

[31] Philip, M. S. (1994): Measuring Trees and Forests. 2nd ed. - CAB International, Wallingford.

[32] Pretzsch, H. (2003): The elasticity of growth in pure and mixed stands of Norway spruce (Picea abies (L.) Karst.) and common beech (Fagus sylvatica L.). - Journal of Forest Science 49: 491-501.

[33] Ralston, R., Buongiorno, J., Fried, J. S. (2004): Potential yield, return and tree diversity of managed, uneven aged Douglas fir stands. - Silva Fennica 38: 55-70.

[34] Reineke, L. H. (1933): Perfecting a stand-density index for even-aged stands. - Journal of Agricultural Research 46: 627-638.

[35] Schütz, J. P. (1975): Dynamique et conditions d'équilibre de peuplements jardinés sur les stations de la hêtraie à sapin. - Schweizerische Zeitschrift für Forstwesen 126: 637-670.

[36] Schütz, J. P. (2001): Opportunities and strategies of transforming regular forests to irregular forests. - Forest Ecology and Management 151: 87-94.

[37] Schütz, J. P. (2002): Silvicultural tools to develop irregular and diverse forest structures. - Forestry 75: 329-337.

[38] Schütz, J. P., Pommerening, A. (2013): Can Douglas fir (Pseudotsuga menziesii (Mirb.) Franco) sustainably grow in complex forest structures? - Forest Ecology and Management 303: 175-183.

[39] Smith, D. M. (1962): The Practice of Silviculture. 7th edn. - Wiley, New York.

[40] Smith, D. M., Larson, B. C., Kelty, M. J., Ashton, P. M. S. (1997): The Practice of Silviculture: Applied Forest Ecology. - John Wiley and Sons, New York.

[41] Spellerberg, I. F., Fedor, P. J. (2003): A tribute to Claude Shannon (1916-2001) and a plea for more rigorous use of species richness, species diversity and the 'ShannonWiener' Index. - Global Ecology and Biogeography 12: 177-179.

[42] Spiecker, H. (2003): Silvicultural management in maintaining biodiversity and resistance of forests in Europe - temperate zone. Journal of Environmental Management 67: 55-65.

[43] Sterba, H. (2004): Equilibrium curves and growth models to deal with forests in transition to uneven-aged structure - application in two sample stands. - Silva Fennica 38: 413-423.

[44] Sterba, H., Monserud, R. A. (1993): The maximum density concept applied to unevenaged mixed stands. - Forest Science 39: 432-452.

[45] Sterba, H., Ledermann, T. (2006): Inventory and modelling for forests in transition from even-aged to uneven-aged management. - Forest Ecology and Management 224: 278285.

[46] von Detten, R. (2011): Sustainability as a guideline for strategic planning? The problem of long-term forest management in the face of uncertainty. - European Journal of Forest Research 130: 451-465. 
[47] Weiner, J., Solbrig, O. T. (1984): The mean and measurement of size hierarchies in plant populations. - Oecologia 61: 334-336.

[48] Whitmore, T. C. (1989): Canopy gaps and the two major groups of forest trees. - Ecology 70: $536-538$.

[49] Woodall, C. W., Miles, P. D., Vissage, J. S. (2005): Determining maximum stand density index in mixed species stands for strategic-scale stocking assessments. - Forest Ecology and Management 216: 367-377.

[50] Woodall, C. W., Miles, P. D., Vissage, J. S. (2016): Determining maximum stand density index in mixed-species stands for strategic-scale stocking assessments. - Forest Ecology and Management 216: 367-377.

[51] Woods, A. J. (2003): Species diversity and forest health in northwest British Columbia. Forest Chronicle 79: 892-897.

[52] Yang, T. R., Lam, T. Y., Kershaw, J. A. (2018): Developing relative stand density index for structurally complex mixed species cypress and pine forests. - Forest Ecology and Management 409: 425-433.

[53] Zeide, B. (2005): How to measure stand density. - Trees 19: 1-14. 